\title{
Research on Integration Conception of Urban and Rural Endowment Insurance System
}

\author{
Wu Yuanyuan \\ Department of Law and Administration, HEBEI GEO \\ UNIVERSITY \\ Shijiazhuang, China \\ wyy1408@sina.com
}

\author{
Yuan Yuan \\ Department of Law and Administration, HEBEI GEO \\ UNIVERSITY \\ Shijiazhuang, China \\ yuanyuan_3007@126.com
}

\begin{abstract}
China's pension system mainly includes Civil Servant Pension System, the Endowment Insurance of Urban Workers and Endowment Insurance for Urban and Rural Residents, which is a fragmented state. This article hopes to establish a step-by-step integration of the endowment insurance system, in which the pension benefits of different regions and different occupation personnel only are related to labor input, so as to realize social fairness. The integration of the endowment insurance system consists of state pension, the employee pension and employment annuity system and personal saving pension.
\end{abstract}

Keywords-The Endowment Insurance System; Integration; The Four Pillar; Fragmentation

\section{INTRODUCTION}

The process of urbanization is depended on the support of social security system, while endowment insurance is the most important part of the social security, so the integration of urban about rural endowment insurance is extremely important for the process of urbanization The integration of the endowment insurance system consists of state pension, the employee pension and employment annuity system and personal saving pension. This article analyses the present problems existed in our country's endowment insurance system, and proposes the ideas and suggestions to establish an integration of the endowment insurance system step-by-step.

\section{Situation ANALysis of Endowment InSURANCE SYSTEM}

China's pension system mainly includes the Civil Servant Pension System, the Endowment Insurance of Urban Workers and the Endowment Insurance for Urban and Rural Residents.

\section{A. Introduction of Three Endowment Insurance System}

In our pension system, the Endowment Insurance of Urban Workers is the largest part, which mainly covers all kinds of urban enterprises workers and some flexible town employees. Urban workers pension contribution is divided into two parts, one part is $8 \%$ of employees' salaries, which is paid by individuals and incorporated into personal accounts; the other part is $20 \%$ of employees' salaries, which is paid by companies monthly and incorporated into social pooling accounts.
The Civil Servant Pension System covers most of the employees of government agencies and institutions. On Jan. 14, 2015, the State Council issued the file of "Decision on The Reform of Endowment Insurance System for Civil Servant Staff", which preludes to the reform of Civil Servant Pension System. The reformed Endowment Insurance System is basically the same to the endowment insurance of urban workers, which have the same contribution rate, calculated method and the establishment of occupational pension, but differ in regulatory agencies and coordinating bodies.

\section{B. Difference Analysis of Three Endowment Insurance System}

From the point of view of system operating mode, Civil Servant Pension System is in the transfer stage from PAYG (pay-as-you-go) system to partially funded system. The Endowment Insurance of Urban Workers adopts the partially funded system, which is the integration of completely accumulation of individual account and PAYG of social pooling account. While Endowment Insurance for Urban and Rural Residents can be viewed as a fully accumulated system because the ultimate pension is determined primarily by the individual account.

From the point of view of financial support, enterprise payment is the main part of the Endowment Insurance of Urban Workers, government will not bear the financial subsidies responsibility of payment link, only serves as the last line of defense. That is to say government finance only acts as an implicit responsibility in the Endowment Insurance of Urban Workers. In the urban and rural residents pension system, payment uses a non-proportional system, which supplies different grade level of payments for urban and rural residents to choose based on their own conditions, then the government will give different subsidies to different level of payments, which will be deposited into the personal accounts of urban and rural residents, obviously the government finance provides a large number of subsidies for the urban and rural residents pension.

In terms of payment of pensions, retirement pension of enterprise employees is calculated on the basis of social average salary, then paid according to the basic pension for enterprise employees and individual accounts pension. While urban and rural residents' pension benefits paid by the state basic pension and individual accounts pension. 


\section{DEFECT ANALYSIS OF ENDOWMENT INSURANCE SYSTEM}

Defects of the pension system mainly exist in two aspects: Firstly, the difference between the treatment of the system is relatively large; secondly, it is difficult to transfer connection.

\section{A. Big Difference Exits in Treatment of Systems}

Differences in treatment cause by calculated method is the main reason why treatment differs big between the three pension systems in our country. The pension level of civil servants is high before the system reformation, which is much higher than other pension systems in treatment, although substantial reforms is carried out, but its effect remains to be tested.

Pooling account of basic pension of urban workers is $50 \%$ of the average value of social average salary and worker mean monthly wage that is indexed. Individual account annuities is provided based on the accumulate savings of pension in personal account divided by the calculated month. Personal pension level is determined by individual contributions and social average wages.

For urban and rural residents, their pension is almost entirely composed of individual pension accounts, the treatment is highly correlated with the individual contributions. But in reality, urban and rural residents choose the lower grade insurance that results in lower accumulation in their personal savings account, furthermore, pension will be affected by its limited ability to increase or keep the value and inflation, when reaching the age to draw the pension, urban and rural residents are not well protected.

\section{B. Difficult Transfer between Different Systems}

The file named "Basic Pension Relation Transfer and Connection Interim Measures for Urban Enterprise Workers" provides that: if insured worker flows at cross-regional then his basic pension insurance relation should be transferred to the new insured region, payment time is calculated together, the balance of individual account is calculated accumulatively, pooling funds transferred by the sum of $12 \%$. Such a transfer connection measures will bring the game problem between move out place and move in place. As for the former, people move out will alleviate pressure on local pension and will have $8 \%$ extra income to make up the overall pension funds of the region, for the latter, only $12 \%$ of overall funds to be transferred into its account, while local government will have to assume pension provision and administration responsibility for the people who move in, which does not have any interest. Therefore, it is easy to move out but difficult to move in for the pension relation, even some cities refuse to accept older workers' pension insurance relation under various pretexts, which restricts the normal orderly flow of labor to some extent.

\section{INTEGRATION OF URBAN AND RURAL ENDOWMENT INSURANCE SYSTEM}

Through above analyses, whether the difference between the treatment system or transfer and renewing problem is because there is no uniform system, so it is important to build a unified pension system step by step. The so-called endowment integration is not to provide the exactly same level of pension for all different labor, the final level of pension will be determined by different labor value, different social contribution and so on. The integrated endowment system we want to build is to make different groups of people in society can obtain the fair pension with their social contribution under the same endowment system.

\section{A. The First Step: Establishment of Social Insurance Information System}

To introduce a national social insurance card and establish the national social insurance information database is the first and key step of establishing an integrated pension system. Firstly, a national database of insured persons and the database of urban and rural residents should be established, which can be realized in two steps, first, to establish the database of province, then to interconnect all the database of province. The national network of social insurance information database can help the laborers to find out their corresponding pension insurance no matter where they are and what department they are in, which will lay a solid foundation for the next step to realize national co-ordination.

\section{B. The Second Step: Pension Calculation with Classification Segment and Accumulation}

To establish the integrative pension system, the interior problem of each branch should be treated better. Therefore, the second step, so-called double insurance brought by pension relation transfer and connection should be solved well. A person may be engaged in the different occupations in many places in his lifetime. As for the highly mobile insured people, the kind of insurance may be various when they are engaged in the different job, that is to say the double insurance is inevitable, but the accumulation of count treatment is not contradictory. If a person who has been paid Civil Servant Pension and the Endowment Insurance of Urban Workers all for at least 15 years, then his pension should be provided by Civil Servant Pension and the Endowment Insurance of Urban Workers together rather than integrated calculation after transfer the benefits and funds from a kind of insurance to another, which will be a loss of insurance for insured people.

Therefore, the best way to calculate pension is to adopt method of classification, segment and accumulation, specifically to improve information systems and based on it to calculate the benefits of different pensions separately and provide pension according to the types of insurance rather than merger the different insurance generally. Upon reaching pension conditions, the pension fund will be remitted into the account where the final pension relationship located in according to the percentage of contributions in different areas on personal total contributions by the local social insurance agencies. In this way not only the status of the coexistence of the three pension system is respected to ensure the relative independence of their own funds, but also the unfairness issues caused by payment years conversion can be avoided. 


\section{The Third Step: Pension System Reform according to the "Four Pillars"}

Now a "Four Pillars" pension model are widely used in the world, in this system, every member who reaches legal and emeritus age in a society, whether or not participated in social work, are entitled to general protection of the first pillar - the State Pension. If he participates in social work, he can enjoy the second pillar - employee pensions, which is run by the state and associated with work.

Moreover, social workers can also enjoy the third pillar Occupational pension (supplementary pension insurance), which is undertaken by the vocational foundations, corporate foundations or insurance company for the industry or enterprise. The fourth pillar is called individual savings pension insurance which is accumulated by Personal accumulation. The "Four Pillars" pension model is reasonable relatively, China should establish an integrated endowment system by using this mode.

\section{1) Construction of the National Pension for Everyone}

State pension for everyone is supplied by the state for every old person, which is the responsibility of the government's commitment to the people, paid by the government guarantee. To ensure the continuity of the system, the amount of this kind of pension need not very big, only to meet the basic living needs of retirees. Basic old-age pension in the Endowment Insurance for Urban and Rural Residents is entirely borne by the State and with the nature of the state pension, but the amount of this part is too little to meet the pension requirements. The lack of the pension system of direct national responsibility is one of the most important drawbacks, which will be the key point of the development of the integration of pension system in the future.

\section{2) Rationalization of the Employee Pension}

Whether enterprise workers or staff of government organizations and institutions, they are members of social workers, participate in social work and create social wealth, and should be provided pension by national nondiscriminatory pension system. Social workers in different professions, different sectors or different regions should participate in a unified pension system, which has the same system design, the same contribution rate, and the same plan hair method, the situation of fragmental pension system will be ended completely.

As a second pillar of pension system, the unified employee pension system will facilitate the rational flow of human resources, reduce pension management costs significantly, increase sense of fairness of members in society and promote the society stabilization and development.

\section{3) Strengthen the Employment Annuity System}

The Employment Annuity System is supplementary pension that is dominated by the employer and established for the laborer of organization, which is the third pillar of the entire pension system. Development of China's supplementary pension is relatively slowly, the employment annuity system is only carried on in a few large companies, while the implementation framework of the employment annuity system is only formulated recently for government organizations and institutions. In the future, the Employment Annuity System will be combined and called occupational pension based on its existing development, then all the various types of workers will be included into the security areas, legislation will be improved, the minimum contribution rate of employees and employers will be set, management style will be limited, the favorable tax is maximized to promote the rapid development of the third pillar (Occupational Pension) and increase its proportion in the whole pension system.

\section{4) Encouragement of Personal Saving Pension}

As a pillar of the endowment insurance system, China's personal saving pension only remains in the preliminary stage of personal spontaneous saving, it is advocated in our country but without any practical measures to encourage. To make personal saving pension truly become a major pillar of the pension insurance system, the state must introduce commercial insurance legislation in social security, strengthen the management of commercial insurance companies, specify the investment scope of the individual pension, risk-sharing mechanisms and liability reserves. When setting up such pension system (the Fourth Pillar Pension System), can we make people willing to transfer money from bank to commercial pension insurance in order to obtain a higher income.

\section{ACKNOWLEDGMENT}

It takes several months to finish the article, which includes topic design, document capture, frame system construction, conclusions analysis and paper writing. First of all, I want to express thanks to my colleagues for their discussion on this topic, exchange of views and many valuable suggestions.

Meanwhile, show my sincere thanks for all the scholars the article involved, for Research results of theirs are referred in the article, it will be difficult for me to complete the article without the help and inspiration of them.

Finally, I am especially grateful for the advocates and organizers of the meeting, you give me an opportunity to explain some of their academic point of view.

\section{REFERENCES}

[1] Bingwen Zheng, "Social Security Development and Challenges of Chinese Migrants during the 30 Years of Reform and Opening up," Chinese Journal of Population Sciences, 2014, (1), pp. 45-58.

[2] Gongcheng Zheng, "Social Security-Concept, System, Practice and Speculation," The Commercial Press, Beijing, China, 2012, pp. 1-478.

[3] Heng Xi, Shaoguo Zhai, "from Ideal Model to Top-level Design: Reflections on China's Pension System Reform," Journal of Wuhan University of Science and Technology (Social Sciences), 2012, (12), pp. 581-583.

[4] Huaizhong $\mathrm{Mu}$, "International Comparison of Social Security (2nd Edition)," China Labor and Social Security Publishing House, Beijing, China, 2012, pp. 169-191.

[5] Robert Pogson, “China's Pension System Reform," Globalization, 2014, (1), pp. 48-58.

[6] Zhen Li, "Social Security Theory (Second Edition)," China Labor and Social Security Publishing House, Beijing, China, 2012, pp. 3-173. 